\title{
Implementasi Manajemen Keragaman Sumber Daya Manusia
}

\section{Implementation of Human Resources Diversity Management}

\author{
Osfred Umbu Djadji ${ }^{1)}$, Roos Kities Andadari ${ }^{2)}$ \\ ${ }^{1,2)}$ Fakultas Ekonomika dan Bisnis, Universitas Kristen Satya Wacana, Kota Salatiga \\ e-mail korespondensi: osfredumbu78@gmail.com
}

\begin{tabular}{|l|}
\hline Info Artikel \\
\hline Riwayat Artikel : \\
Diterima: 04 Juni 2020 \\
Disetujui: 30 Juli 2020 \\
Dipublikasikan: Januari 2021 \\
\hline Nomor DOI \\
10.33059/jseb.v12i1.2348 \\
Cara Mensitasi : \\
Djadji, O. U., \& Andadari, R. \\
K. (2021). Implementasi \\
manajemen keragaman \\
sumber daya manusia. Jurnal \\
Samudra Ekonomi dan Bisnis, \\
12(1), 62-75. doi: 10.33059/ \\
jseb.v12i1.2348.
\end{tabular}

\begin{abstract}
Penelitian ini bertujuan untuk memberikan gambaran tentang implementasi, bentuk pelaksanaan dan permasalahan yang ditemui dalam implementasi manajemen keragaman dalam kaitannya dengan praktik manajemen sumber daya manusia (MSDM) di UKSW. Penelitian kualitatif ini dilakukan melalui studi kasus. Narasumber dalam penelitian ini adalah empat orang pimpinan universitas dan seorang staf. Data diperoleh melalui proses wawancara mendalam dan kemudian dianalisis dengan tiga teknik deskriptif. Hasil penelitian menunjukan bahwa praktik implementasi manajemen keragaman MSDM telah dilakukan dengan baik yang berbasis pada kinerja, adil dan tidak terdapat perlakuan diskriminasi. Permasalahan implementasi yang ditemui pada situs penelitian terbagi menjadi dua bagian, yaitu praktik di dalam dan di luar MSDM. Permasalahan praktik di dalam MSDM terjadi pada tahap pelatihan dan tahap promosi; sementara permasalahan yang terjadi diluar praktik MSDM seperti masalah komunikasi dan cara pandang yang berbeda-beda.
\end{abstract}

Kata Kunci: Praktik MSDM, Keragaman, Manajemen Keragaman.

\begin{tabular}{|l|}
\hline Article Info \\
\hline Article History : \\
Received: 04 June 2020 \\
Accepted: 30 July 2020 \\
Published: January 2021 \\
\hline DOI Number : \\
10.33059/jseb.v12i1.2348 \\
How to cite : \\
Djadji, O. U., \& Andadari, R. \\
K. (2021). Implementasi \\
manajemen keragaman \\
sumber daya manusia. Jurnal \\
Samudra Ekonomi dan Bisnis, \\
12(1), 62-75. doi: 10.33059/ \\
jseb.v12i1.2348.
\end{tabular}

\section{Article Info}

DOI Number :

How to cite :

Djadji, O. U., \& Andadari, R. K. (2021). Implementasi manajemen keragaman Samudra Ekonomi dan Bisnis, jseb.v12i1.2348.

\section{Abstract}

The purpose of this research is to provide an overview of the implementation, forms of implementation and problems encountered in implementing diversity management in relation to human resource management (HRM) practices at $S W C U$. This qualitative research conducted through case studies. Key persons in this study were four university leaders and one staff member. Data obtained through in-depth interview process and then analyzed in three descriptive techniques. The results showed that the practice of implementing HR management diversity management was carried out well based on performance, fair and there was no discrimination. The implementation problems encountered at SWCU are divided into two parts, namely practice inside and outside the HRM. Practical problems in HRM occur at the training and promotion stages; and, problems that occur outside the HRM practice such as communication problems and different perspectives.

Keywords: HRM Practices, Diversity, Diversity Management. 


\section{PENDAHULUAN}

Organisasi sebagai penyedia lapangan kerja menginginkan kinerja yang optimal dari para tenaga kerjanya. Hal tersebut dibatasi karena fenomena globalisasi yang menyebabkan terjadinya masalah dalam menciptakan dan mengelola keragaman yang berbeda di sektor pendidikan, sektor publik, kesehatan, swasta, media dan di tempat kerja (Hunt, 2007; Sharma, 2016; Ali et al., 2013; Harrisr \& Foster, 2010; Cooke \& Saini, 2012). Keragaman adalah istilah yang luas serta frase "keragaman tempat kerja" (workplace diversity) yang didasarkan pada karakteristik seseorang berbeda dari yang lainnya.

Perbedaan karakteristik memberikan suatu kekayaan lingkungan bagi organisasi karena dapat membuat sudut pandang dan produktivitas yang lebih besar tetapi tidak semua memiliki hasil yang positif (Horwitz \& Horwitz, 2007; Greenberg et al., 2009). Kenyataannya, pengelolaan keragaman di organisasi masih menimbulkan masalah dan seringkali terjebak pada konflik yang membuat orang tidak menghargai keragaman serta tidak adanya cara dari organisasi untuk memanfaatkannya (Bedi et al., 2014).

Berdasarkan hasil survei yang dilakukan oleh pakar global, Michael Page di tahun 2018 menunjukkan bahwa dalam memperkerjakan karyawan setiap organisasi di Indonesia cenderung memberikan prioritas perbedaan pada gender, agama, ras dan etnis (www.michaelpage.co.id). Hasil itu didukung dengan penelitian Foley et al., (2015) yang menjelaskan organisasi di China cenderung merekrut karyawan dengan berpatokan pada aspek gender. Sedangkan menurut Stainback et al., (2018) organisasi di Amerika Serikat mempekerjakan karyawan dengan selalu mempertimbangkan aspek ras dan etnis yang dimiliki. Selain itu, perkembangan zaman, konsep dan kebijakan organisasi terus berkembang dan berbeda dikarenakan isu-isu keragaman seperti gender, umur, kesempatan kerja, kemampuan, ras dan etnis di setiap organisasi dan negara berbeda (Ahonen \& Tienari, 2009).

Penelitian terdahulu yang dilakukan oleh Patrick \& Kumar (2012) serta Ayega \& Muathe (2018) menjelaskan bahwa organisasi yang mampu mengelola keragaman dengan baik akan menciptakan karyawan yang memiliki komitmen, kepuasan, kinerja tinggi dan mampu membuat organisasi mencapai keunggulan. Keragaman karyawan dalam organisasi memberikan kontribusi secara langsung terhadap inovasi (Hudson, 2014). Garg \& Panchal (2016) mengatakan bahwa keragaman dalam organisasi sangat penting karena memiliki keuntungan kompetensi sehingga dibutuhkan manajemen keragaman guna mampu mengurangi gesekan antar karyawan. Keragaman tenaga kerja adalah sebuah kekuatan bagi organisasi meskipun banyak orang menilai dari kasta, agama, dan lain-lain sebagai suatu konflik tetapi jika dikelola dengan baik maka akan meningkatkan produktivitas organisasi (Saxena, 2014).

Beberapa penelitian empiris telah memperlihatkan bahwa keragaman jika dikelola dengan baik akan meningkatkan komitmen, kepuasan, kinerja organisasi, mengurangi terjadinya konflik dan diskriminasi. Universitas Kristen Satya Wacana adalah universitas yang dijuluki sebagai "Indonesia mini" karena banyak berkumpul mahasiswa, Staf dan Dosen yang berasal dari berbagai macam ras dan etnis yang ada di seluruh Indonesia. Hal tersebut tercermin dari rangkuman data yang ditunjukkan dalam Tabel 1. Data dalam Tabel tersebut memperlihatkan bahwa Staf dan Dosen yang bekerja di Universitas Kristen Satya Wacana Salatiga (UKSW) memiliki keragaman dari agama, gender, umur, masa kerja, ras dan etnis. Karena itu, keragaman yang telah ada sangat penting dan perlu untuk dikelola agar tujuan organisasi dapat tercapai. 
Tabel 1. Jumlah Staf dan Dosen UKSW Tahun 2019

\begin{tabular}{|c|c|c|c|c|c|c|}
\hline \multirow{2}{*}{ Jabatan } & \multicolumn{2}{|c|}{ Gender (org) } & \multirow{2}{*}{ Usia (thn) } & \multicolumn{2}{|c|}{ Ras dan Etnis (\%) } & \multirow{2}{*}{ Total (org) } \\
\hline & Pria & Wanita & & Jawa & Luar & \\
\hline Dosen & 251 & 208 & $30-70$ & 80 & 20 & 459 \\
\hline Non Dosen/Staf & 286 & 131 & $30-60$ & 90 & 10 & 417 \\
\hline Total & & & & & & 876 \\
\hline
\end{tabular}

Sumber: Yayasan Perguruan Tinggi Kristen Satya Wacana, 2019 (diolah).

Berdasarkan latar belakang itu, maka bisa muncul permasalahan tentang bagaimana implementasi manajemen keragaman dalam praktik Manajemen Sumber Daya Manusia (MSDM) yang meliputi: rekrutmen, seleksi, promosi, pelatihan, kompensasi serta pemberian jaminan kesehatan yang didasarkan pada aspek agama, gender, umur, masa kerja, ras dan etnis di Universitas Kristen Satya Wacana. Selain itu, penelitian tentang implementasi manajemen keragaman kaitannya dengan praktik MSDM masih relatif sedikit.

Secara spesifik, tujuan dalam penelitian ini yaitu untuk memberikan gambaran tentang implementasi, bentuk pelaksanaan dan permasalahan yang ditemui dalam implementasi manajemen keragaman terkait dengan praktik MSDM di UKSW. Penelitian ini diharapkan menjadi informasi yang dapat digunakan sebagai referensi dan sebagai bahan pertimbangan dalam mengelola dan menerapkan keragaman sehingga tidak akan menimbulkan konflik dan diskriminasi. Penelitian ini juga diharapkan dapat menambah pengetahuan dan wawasan bagi pihak yang membutuhkan serta bisa dijadikan sebagai pedoman untuk mengembangkan penelitian selanjutnya.

\section{Keragaman}

Keragaman adalah ciri khas individu yang membuatnya berbeda dari individu yang lain (Gómez-Mejia et al., 2012). Robbins \& Judge (2015) menjelaskan keragaman adalah bentuk perbedaan individu yang dipengaruhi oleh karakteristik biografis maupun karakteristik pribadi. Karakteristik biografis adalah per-bedaan yang mudah dinilai secara langsung seperti umur, jenis kelamin, ras dan etnis, disabilitas, masa kerja, gender, agama, identitas budaya. Sedangkan karakterisitik kepribadian adalah karakteristik perbedaan nilai-nilai kepribadian seseorang untuk menentukan kesamaan jika seseorang semakin mengenal orang lain.

Menurut Hayes \& Niemeier (2009), keragaman adalah perbedaan seseorang yang dipengaruhi oleh dimensi primer dan dimensi sekunder. Dimensi primer adalah dimensi yang dipengaruhi usia, gender, kemampuan fisik, orientasi seksual, ras dan etnis. Sedangkan dimensi sekunder dipengaruhi oleh pendidikan, status keluarga, peran dan tingkat organisasi, agama, bahasa, pendapatan, lokasi geografis, dan lainnya. Sedangkan menurut Ardakani et al. (2016), keragaman adalah perbedaan yang dipengaruhi oleh kepribadian, dimensi internal, dimensi eksternal, serta dimensi organisasi. Dimensi internal meliputi usia, gender, orientasi seksual, kemampuan fisik, ras dan etnis. Dimensi eksternal yaitu letak geografis, kebiasaan pribadi, pendapatan, agama, pendidikan, pengalaman kerja, status perkawinan dan penampilan orang tua. Dimensi organisasi yaitu status manajemen, bidang pekerjaan, afiliasi serikat pekerja, senioritas, klasifikasi fungsional, divisi atau kelompok, dan lokasi kerja.

\section{Manajemen Keragaman}

Menurut Bangun (2012), manajemen keragaman merupakan langkah yang diambil untuk memaksimalkan potensi keragaman 
dengan perbedaan-perbedaan yang dimiliki oleh individu seperti seperti gender, umur, masa kerja, disabilitas, agama, identitas budaya, ras dan etnis dan lain-lain untuk mencapai kinerja yang efektif. Sedangkan Thomas (2012) memberi penjelasan bahwa manajemen keragaman adalah kesanggupan individu dalam membuat suatu keputusan yang berkualitas berkaitan dengan kesamaan ditengah perbedaan agar tidak menimbulkan ketegangan. Manajemen keragaman adalah pemberian fasilitas kepada pekerja dengan latar belakang yang berbeda agar turut mengikuti proses dan tujuan organisasi untuk mencapai keunggulan yang kompetitif (Femi \& Prasetya, 2017).

\section{Praktik-Praktik Implementasi Manajemen Keragaman MSDM}

Konsep manajemen keragaman banyak digunakan sebagai bagian dalam MSDM dan telah diterapkan pada negara yang kurang berkembang serta pada organisasi lokal maupun multinasional (Cooke \& Saini, 2012). Menurut Femi \& Prasetya (2017), praktikpraktik implementasi manajemen keragaman di dalam lingkup MSDM dilakukan dengan rekrutmen, seleksi, pelatihan, promosi, kompensasi dan pemberian jaminan Kesehatan dan Keselamatan Kerja (K3). Sedangkan menurut Meena \& Vanka (2017), praktik implementasi manajemen dapat dilakukan dengan menerapkan 7 (tujuh) proses, yaitu: (1) seleksi, (2) evaluasi, (3) pelatihan, (4) kompensasi, (5) kontrol, (6) bebas identitas, dan (7) praktik kelompok.

Menurut Roberge et al. (2011), praktik implementasi manajemen keragaman dapat ditunjukkan dengan adanya keadilan dalam memberikan promosi dan pelatihan dalam organisasi. Praktik implementasi manajemen keragaman bisa dilakukan dengan pemberian kompensasi, pelatihan dan komunikasi kepada karyawan (Roh \& Kim, 2016).

\section{Bentuk Implementasi Manajemen Keragaman}

Bentuk implementasi dari manajemen keragaman di dalam organisasi dapat dilakukan dengan menyediakan fasilitas kerja dan keagamaan untuk mendukung kegiatan karyawan, memberi cuti, pemberian jaminan kesehatan dan memberikan wadah aspirasi melalui serikat pekerja dalam perusahaan (Femi \& Prasetya, 2017). Bangun (2012) menjelaskan bahwa bentuk implementasi manajemen keragaman bisa dilakukan dengan memberikan kepercayaan penuh kepada karyawan minoritas dalam proses melakukan kegiatan organisasi.

Menurut Kundu \& Mor (2017), bentuk implementasi manajemen keragaman dapat dilakukan melalui pemeliharaan lingkungan kerja yang positif, memastikan karyawan memiliki kesempatan untuk meningkatkan kompetensi dan meningkatkan pengembangan diri karyawan. Jayne \& Dipboye (2004) menjabarkan bentuk implementasi manajemen keragaman dapat dilakukan dengan membantu kerja yang fleksibel, menjalin hubungan kerjasama dengan mitra perusahaan dan menciptakan program untuk menarik serta mempertahankan karyawan. Bentuk implementasi manajemen keragaman dilakukan dengan melakukan penyelarasan atas semua perbedaan karyawan, mengurangi potensi dampak negatif dan menghormati setiap perbedaan antar individu dengan mempromosikan keragaman (Cooke \& Saini, 2012).

\section{Kendala Implementasi Manajemen Keragaman}

Menurut Abugu \& Jerry (2018), kendala implementasi manajemen keragaman disebabkan karena tidak adanya komunikasi, perlawanan budaya, diskriminasi, biaya meningkat, masalah integrasi, hubungan tempat kerja, berbagai akomodasi, pelatihan wajib 
dan mempekerjakan otoritas manajer. Sedangkan menurut Femi \& Prasetya (2017), kendala ataupun hambatan implementasi manajemen keragaman disebabkan tidak seimbangnya jumlah karyawan laki-laki dan perempuan, gap antara tenaga kerja yang masuk dan keluar, kurangnya fasilitas dan adanya kebijakan pemerintah serta perubahan situasi ekonomi yang cepat.

Menurut Ali et al. (2013), kendala atau hambatan implementasi manajemen keragaman disebabkan karena adanya protes dari karyawan dalam merekrut karyawan asing. Sedangkan menurut Choi \& Rainey (2010), kendala ataupun hambatan implementasi manajemen keragaman disebabkan karena adanya keluhan dari karyawan yang beragam seperti usia, ras dan etnis dan gender berkaitan dengan kesetaraan kesempatan kerja serta perlakuan diskriminasi dalam hal gender, ras dan etnis. Kendala atau hambatan implementasi manajemen keragaman disebabkan karena tidak adanya dukungan dari karyawan pria di dalam mempromosikan keragaman dan karyawan pria tidak menghargai pimpinan yang merekrut maupun mempertahankan karyawan yang beragam.

\section{METODE PENELITIAN}

Penelitian ini menggunakan jenis penelitian deskriptif dengan pendekatan kualitatif. Sumber data dalam penelitian ini adalah data primer yang diperoleh dengan wawancara. Narasumber dalam penelitian ini adalah pimpinan universitas meliputi Pembantu Rektor 1 dan 2, Kepala dan staf Biro Pengembangan Sumber Daya Manusia serta Wakil Dekan Fakultas Ekonomika dan Bisnis Universitas Kristen Satya Wacana. Teknik pengumpulan data dalam penelitian ini yaitu dengan wawancara mendalam kepada narasumber penelitian.

Teknik analisis yang digunakan untuk menjawab persoalan penelitian ini dengan menggunakan tiga macam teknik. Teknik pertama yaitu reduksi data, dilakukan dengan memilih, mengedit dan menghilangkan katakata yang tidak diperlukan atau tidak sesuai dengan penelitian. Data yang direduksi akan memberikan gambaran yang lebih spesifik dan mempermudah dalam pengumpulan data. Teknik kedua adalah penyajian data dilakukan agar data yang telah direduksi dapat tersusun dengan baik agar mudah dipahami. Penyajian data akan dilakukan dalam bentuk uraian narasi. Teknik ketiga yaitu interpretasi data dilakukan dengan menarik kesimpulan dari data yang diperoleh sebagai hasil dari penelitian yang akan disajikan dalam bentuk narasi.

\section{HASIL DAN PEMBAHASAN}

Peran universitas dalam mengelola keragaman yang ada menjadi sangat penting dikarenakan dapat memberikan keunggulan sehingga tujuan organisasi dapat tercapai. Selain itu, peran pengelolaan keragaman dalam organisasi sering dikaitkan dengan praktik MSDM karena memiliki cakupan luas, tidak terbatas dan berbeda di setiap organisasi (Meena \& Vanka, 2017).

\section{Praktik Implementasi Manajemen Keragaman MSDM}

Praktik implementasi dari manajemen keragaman dalam praktik MSDM di UKSW terbagi menjadi enam tahap, yaitu rekrutmen, seleksi, promosi, pelatihan, kompensasi serta pemberian jaminan kesehatan. Keenam tahap tersebut selanjutnya dikaitkan dengan setiap aspek keragaman yang ada, seperti agama, gender, umur, masa kerja, ras dan etnis. Terkait permasalahan ini, beberapa narasumber memberikan pernyataan berikut.

Narasumber pertama (N.1) menyatakan bahwa dalam rekrutmen dan seleksi dari segi agama, umur dan masa kerja, pasti lebih diprioritaskan; tetapi semua itu kembali lagi 
kepada kebutuhan dan tugas. N.1 melihat prinsip yang digunakan oleh Universitas Kristen Satya Wacana yaitu pada umumnya adalah right person and the right place, yaitu mengutamakan keterwakilan dan kapabilitas yang bermuara pada kinerja. Kalau dari promosi, perbedaan lebih penting itu umur dan masa kerja karena saling berkaitan. Dosen rajin meneliti maka dia sudah pasti akan naik. Dari pelatihan, kalau ada keragaman yang sifatnya kemampuan itu kita push dengan pelatihan. Dari aspek kompensasi, dilihat dari segi masa kerja dan posisi yang dijabat. Misalnya kalau pimpinan melihatnya dosen itu kuat sekali di riset, kuat sekali di pengabdian masyarakat dan ada yang kuat sekali di pengajaran, disini bisa dipikirkan satu skema kompensasi atau insentif. Dalam pemberian jaminan kesehatan, semua dosen memperoleh jaminan kesehatan berupa BPJS.

Narasumber kedua (N.2) menyatakan bahwa rekrutmen dan seleksi, agama, gender, umur dan masa kerja (adalah) diperhatikan, hanya saja ada beberapa tugas dan aturan yang dijadikan patokan oleh pihak pimpinan. Promosi untuk dosen yang lebih banyak melakukan penelitian itu biasanya yang dipromosikan pimpinan. Pelatihan biasanya seperti kursus sertifikasi tanpa memandang perbedaan agama, gender, umur, masa kerja, ras dan etnis, dan pimpinan memberikan peluang yang sama untuk dosen yang muda dan usia lanjut untuk mengembangkan diri dalam berbagai forum penelitian. Kompensasi, yang biasanya membedakan dalam umur dan masa kerja karena keduanya ini saling berkaitan. Dari segi jaminan kesehatan, sesuai dengan peraturan pemerintah dan BPJS. Jadi berdasarkan masa kerja karena iurannya berbeda juga.

Narasumber ketiga (N.3) menyatakan rekrutmen dan seleksi dari aspek agama, gender, usia dan masa kerja dipertimbangkan. Jadi tergantung jenis pekerjaan yang dibutuh- kan. Promosi, dari segi umur, Kalau untuk dosen, ada sistemnya sendiri yaitu dia harus banyak penelitian. Untuk pelatihannya, semua mendapatkan kesempatan yang sama dan selama ini biasanya di dalam kampus dan diluar juga pernah seperti kursus. Dari segi kompensasi, hanya saja yang membedakan itu masa kerja. Dari segi jaminan kesehatan, dosen semuanya dapat, tanpa memandang agama, gender, umur, masa kerja, ras dan etnis.

Narasumber keempat (N.4) berpendapat bahwa dalam rekrutmen dan seleksi, pohak pimpinan tidak memandang suku. Dari aspek agama, tapi kalau untuk dosen tetap, agama tetap diutamakan karena ini kewenangannya yayasan. Gender tidak ada perbedaan kecuali jenis pekerjaannya. Dari aspek umur dan masa kerja dibatasi karena sudah aturan dari yayasan. Pelatihan dari SDM itu ada dua, yaitu people development atau pengembangan orang itu kapasitas atau talentanya sebagai pimpinan, dengan organizational development atau pengembangan organisasi seperti pelayanan. Kompensasi dibedakan dari aspek umur dan masa kerja ini saling berkaitan. Kalau untuk dosen itu berdasarkan penelitian. Tetapi kalau suami-istri kerja di Universitas Kristen Satya Wacana, itu yang ditunjang hanya satu orang saja. Pemberian jaminan Kesehatan dibedakan berdasarkan aspek umur dan masa kerja, yaitu jika tenaga kerja yang berpenghasilan tinggi itu biasanya akan diberikan iuran yang tinggi juga.

Narasumber kelima berargumen bahwa rekrutmen dan seleksi dari aspek gender seperti yang tadi beliau sudah sampaikan, tergantung dari kebutuhan dan komposisi itu sedapat mungkin dijaga. Dari aspek umur dan agama, ada batasan karena semua yang atur itu yayasan untuk merekrut dosen. Rekrutmen kita tidak membatasi pada ras tertentu, tetapi memang bottom line-nya adalah kembali lagi pada profesionalitas dan kompetensi tadi. 
Promosi yang berlaku tidak mengenal itu. Selagi dia punya kemampuan maka institusi dukung karena punya karakteristik masingmasing, jadi tidak dibatasi itu. Pemberian kompensasi dan jaminan kesehatan kepada Dosen didasarkan pada lama masa kerja dan golongan yang tinggi. Secara otomatis, kompensasi yang diterima tinggi sehingga iuran jaminan kesehatan yang akan diberikan tinggi juga. Pelatihan diberikan sesuai kebutuhan atau master plan. Jadi semua sesuai dengan renstra yang dimulai dengan program kerja yang sudah disusun.

Universitas Kristen Satya Wacana (UKSW) menjalankan fungsi MSDM sebagai bagian dari praktik implementasi manajemen keragaman. Keenam tahap yang telah dipaparkan diatas didukung dengan penelitian yang dilakukan oleh Femi \& Prasetya, (2017) serta Meena \& Vanka (2017) menjelaskan praktik implementasi manajemen keragaman dapat dilakukan dengan rekrutmen, seleksi, pelatihan, promosi, kompensasi dan pemberian jaminan kesehatan.

Hasil penelitian laiinya menunjukkan bahwa tahapan rekrutmen, seleksi, promosi, pelatihan dan kompensasi didasarkan pada prinsip the right man and the right place. Prinsip tersebut menjadi tolok ukur UKSW dalam merekrut, memilih, mengangkat, menempatkan, melatih dan memberi kompensasi kepada Dosen sesuai dengan kapabilitas yang dimiliki yang kemudian akan berbasis pada kinerja. Tujuan diterapkan prinsip tersebut agar mendapatkan sumber daya yang berkualitas sehingga tujuan organisasi dapat dicapai. Hasil tersebut didukung dengan studi yang dilakukan oleh Horwitz \& Horwitz (2007) yang menyebutkan bahwa keragaman dapat juga dapat dilihat lebih spesifik lagi seperti sikap dan nilai-nilai yang tidak terlihat. Manajemen keragaman merupakan sebuah pendekatan inklusif dengan merekrut, memilih, mengangkat serta menempatkan karyawan sesuai dengan kamampuan dan pengalaman yang dimiliki (Bleijenbergh et al., 2010).

Hal yang berbeda dapat dijumpai pada tahap pemberian jaminan kesehatan yang diberikan tanpa memandang perbedaan agama, gender, umur, kapabilitas, ras dan etnis. Salah satu aspek yang menjadi ukuran dalam memberikan jaminan kesehatan adalah masa kerja karena menentukan besar kecilnya iuran yang akan dibayarkan. Selain itu, pada tahap rekrutmen dan seleksi terdapat aspek lain yang menjadi prioritas utama UKSW yaitu adalah agama, umur dan masa kerja yang harus sesuai kriteria perekrutan. Kedua tahap itu telah diatur dalam SOP yayasan dan universitas, sehingga hasilnya tidak terdapat perlakuan diskriminasi dan semua tahap dilakukan dengan adil dan sesuai dengan kebijakan yang telah diatur sebelumnya. Temuan tersebut didukung dengan penelitian yang dilakukan oleh Roberge et al. (2011) yang menjelaskan bahwa kebijakan pengelolaan keragaman yang dilakukan organisasi berguna untuk menghasilkan potensi kinerja positif yang berdampak kepada keadilan melainkan bukan pada potensi negatif seperti diskriminasi. Kebijakan implementasi manajemen keragaman dalam praktik MSDM yang dilakukan organisasi adalah sebuah kekuatan untuk mencegah dari konflik dan diskriminasi sehingga akan mengarah pada hasil positif (Chi et al., 2009).

\section{Pelaksanaan Manajemen Keragaman}

Bentuk pelaksanaan dari manajemen keragaman di UKSW terbagi ke dalam beberapa aspek, seperti agama, gender, umur, masa kerja, ras dan etnis. Untuk problema ini, Narasumber pertama (N.1) menyatakan bahwa dari aspek agama, di UKSW ada ibadah setiap hari Senin pukul 09.00 untuk semua civitas akademika. Jadi semua aktivitas yang berkaitan dengan pelayanan dan 
pengajaran pada jam itu tidak dilakukan, melainkan dilakukan setelah ibadah selesai atau jam 10. Selain itu bagi wanita yang baru melahirkan, pihak institusi membuat ruangan khusus untuk mengganti pakaian, contohnya di gedung elektro. Cuti juga diberikan kepada dosen wanita yang melahirkan selama tiga bulan. Kalau di jajaran rektorat selalu ada yang wanita, jadi dinilai bagus. Dari segi umur, kalau sesuatu itu membutuhkan mobilitas yang tinggi seperti stamina dan pimpinan punya orang yang senior dan beliau sudah tidak bisa disuruh seperti itu, pasti dialihkan. Kalau pimpinan juga melihat dalam kemampuan riset institusi berusaha untuk para dosen yang mungkin bagus kemampuan risetnya tetapi kurang bagus dalam menulisnya, institusi memberikan fasilitas tambahan dengan cara memberikan pelatihan-pelatihan. Dari sisi masa kerja, sama juga dinilai jika pimpinan membutuhkan orang-orang yang berpengalaman. Dari segi ras dan etnis penerapannya, yaitu melihat kemampuannya sesuai dengan tugas yang diberikan, karena setiap ras dan etnis pasti memiliki kemampuan yang berbeda-beda.

Narasumber kedua (N.2) memberikan pendapat bahwa dari segi gender, semuanya sama dan pihak institusi juga memberikan cuti melahirkan dan cuti haid kepada dosen perempuan. Dari segi umur, untuk dosen yang sudah tua itu, institusi memberikan tugas yang tidak banyak dan berat karena membutuhkan fisik sehingga pekerjaannya dialihkan kepada yang lebih muda. Dari segi masa kerja, pengelola institusi memberikan fasilitas ruangan khusus untuk pimpinan unitunit yang sudah memiliki masa kerja dan pengalaman yang lama. Dari segi ras dan etnis semuanya sama, jadi pimpinan memberikan fasilitas kerja yang sama; jadi tidak ada fasilitas ini untuk ras dan etnis tertentu, malah nanti bisa timbul konflik diskriminasi.
Narasumber ketiga (N.3) menyatakan bahwa dari sisi gender, perempuan diberikan cuti melahirkan dan pekerjaan yang melibatkan fisik, tidak akan diberikan ke perempuan. Kaum perempuan juga saat ini diberikan kesempatan kerja yang tinggi, seperti menjadi pimpinan. Terkait umur, penerapannya yang terlihat bahwa banyak senior yang memperlakukan dan membantu juniornya serta saling belajar; artinya ada kesempatan yang dberikan. Berkenaan masa kerja, semakin tinggi pangkatnya maka tugasnya secara langsung juga berbeda; dan dari segi fasilitas kerja, semuanya seperti ruangan khusus, meja dan kursi khusus. Berhubungan dengan ras dan etnis, bentuk penerapannya saat ini adalah adanya kegiatan seperti expo budaya dan yang setiap hari jumat dilakukan, yaitu senam nusantara dengan melibatkan semua etnis berpartisipasi dari mahasiswa sampai dosen.

Narasumber keempat (N.4) memberi argumen bahwa berkenaan dengan aspek agama, terdapat pelaksanaan ibadah di BU setiap Senin; lalu untuk mahasiswa dan pegawai disediakan mushola. Pada aspek gender, UKSW dinilai sudah menghargai kesetaraan gender seperti memberikan kesempatan bagi perempuan untuk bekerja dan menjadi pimpinan pada pekerjaan tertentu. Dengan demikian, UKSW dinilai sangat menghargai karena paling tidak peraturan kepegawaian telah memberikan ruang bagi perempuan yang akan melahirkan untuk cuti selama tiga bulan dan tetap dibayar gajinya apabila dia sudah berstatus tetap. Juga, tidak ada perbedaan kesempatan untuk mengembangkan diri karena laki-laki dan perempuan adalah sama. Terkait umur, pemberian tugas khusus yang beresiko lebih diutamakan yang memiliki fisik sehat dan muda. Pada aspek masa kerja, ada pada unit-unit tertentu yang masa kerjanya lama dikasih tempat yang lebih baik. Dari aspek ras dan etnis, hal itu sudah masuk dalam semua kebijakan dari UKSW. 
Dalam aspek gender, Narasumber kelima (N.5) menyatakan bahwa UKSW juga telah memberikan ruang bagi perempuan yang akan melahirkan untuk cuti selama tiga bulan. Dari segi fasilitas kerja, UKSW memberikan fasilitas tambahan untuk jabatan struktural terkait dengan tugas dan privasinya. Selain itu, dalam perekrutan dosen di UKSW khususnya di Fakultas Ekonomika dan Bisnis, tidak membatasi kuota bagi dosen perempuan; tetapi kalau di universitas negeri, hal itu dinilai dibatasi. Berkenaan dengan aspek umur, pimpinan dinilai telah melakukan dengan memperpanjang kontrak yang sudah usia pensiun karena dengan pertimbangan tertentu, seperti masih kuat dalam bekerja. Pada aspek msa kerja, pihak pimpinan lebih melihat karya-karya yang sudah dilakukan; sehingga bagi dosen yang memiliki masa kerja lama dan berprestasi maka akan diberikan reward atau penghargaan kepada mereka. Terkait aspek ras dan etnis, institusi UKSW telah mengembangkan pola sikap dan perbuatan toleransi di antara dosen yang memiliki ras dan etnis berbeda, karena perbedaan itu tidak harus bersifat memisahkan.

Bentuk pelaksanaan manajemen keragaman di UKSW yang ditemui adalah mengadakan kegiatan ibadah rutin bagi civitas akademika, kesempatan kerja yang sama, pengembangan diri, penyediaan fasilitas ruangan bagi pimpinan dan wanita yang telah melahirkan pemberian cuti, pengalihan pekerjaan yang melibatkan fisik, perpanjangan masa masa pensiun, pemberian penghargaan bagi dosen berprestasi, pemberian kebebasan perekrutan, pengembangan budaya organisasi, mengadakan kegiatan bersifat mempersatukan seperti expo budaya dan senam nusantara. Selain itu juga disediakan pelatihan bagi dosen yang mengalami kesulitan dalam penulisan riset. Hasil temuan itu didukung oleh Femi \& Prasetya (2017) serta Bangun (2012) yang menemukan bahwa implementasi manajemen keragaman dilakukan dengan menyediakan kegiatan keagamaan untuk mendukung kegiatan karyawan, pemberian jaminan kesehatan, kesempatan mengembangkan diri, fasilitas kerja, dan memberikan kepercayaan atau jabatan.

\section{Permasalahan Implementasi Manajemen Keragaman}

Permasalahan yang ditemui pada saat implementasi manajemen keragaman dalam UKSW adalah berkaitan dengan praktik di dalam dan diluar MSDM. Selanjutnya, permasalahan yang ditemui dikaitkan dengan aspek-aspek agama, gender, umur, masa kerja, ras dan etnis.

Berkenaan dengan permasalahan itu, Narasumber pertama (N.1) menyatakan dari sis-sisi gender, umur dan masa kerja, tidak ada masalah. Hal ini karena selama bekerja, beliau merasa telah cukup beruntung melihat kemampuan yang tepat yang mana dan bisa ditugaskan. Untuk aspek ras dan etnis, menurut N1 tidak terjadi persoalan karena proses terjadi transparan. Walau demikian, memang dikhawatirkan bisa terjadi konflik, karena terkadang kalau orang yang dinilai kurang dikenal atau karena masih baru, maka proses penilaian bisa terpeleset paada hal-hal itu. Secara umum, N.1 menyatakan bahwa ia saat ini telah lebih memahami bagaimana menerapkan antisipasi untuk kasus yang bersangkutan seperti itu.

Selanjutnya, Narasumber kedua (N.2) menyatakan bahwa selama ia bekerja, terkait dengan sisi gender, ia tidak menemukan permasalahan karena baik perempuan maupun laki-laki itu memperoleh proses penilaian yang sama. Dari segi umur, masa kerja dan ras dan etnis, juga dinilai tisak bermasalah karena mereka bekerja ini sebagai tim atau teamwork. Sedangkan untuk aspek kebijakan, kalau unsur pimpinan dinilai terlalu banyak campur tangan di tim itu, nanti mereka malah 
menjadi bingung karena merasa seperti tidak dipercaya saat bekerja.

Dari sisi umur sama dengan masa kerja, Narasumber ketiga (N.3) menyatakan bahwa kalau dosen yang umurnya lebih tua dan masa kerja lama itu dinilai lebih susah diaturnya. Lebih jauh, N.3 menilai bahwa tidak ada permasalahan dalam sisi gender, ras dan etnis.

Sementara itu, Narasumber keempat (N.4) menyatakan juga bahwa tidak ada permasalahan dalam institusi UKSW untuk aspek-aspek agama, gender, umur dan masa kerja. Akan tetapi ada permasalahan pada aspek ras dan etnis ada dikarenakan dosen itu cenderung mengajak teman-teman sesama ras dan etnis, sehingga susah memiliki pandangan berbeda-beda dan akan muncul stereotype tertentu.

Narasumber kelima (N.5) menyatakan bahwa terdapat masalah pada aspek gender, karena saat mengutus dosen untuk studi lanjut maka kaum perempuan itu biasanya butuh lebih banyak pertimbangan keluarga. Untuk aspek masa kerja, pihak dosen cenderung sudah merasa dalam zona nyaman dan tidak tertantang untuk melakukan perubahanperubahan yang positif untuk kemajuan organisasi. Selain itu, tidak semua orang berpikir dengan cara yang sama; apalagi dengan kondisi lingkungan tempat tumbuh kembangnya yang berbeda-beda. Jadi kendala yang ada itu terkait dengan cara pandang.

Permasalahan praktik di dalam MSDM karenanya diidentifikasi terjadi pada tahap pelatihan, yang mana terdapat pertimbangan untuk melaksanakan studi lanjut dari pihak keluarga bagi dosen wanita. Selanjutnya pada tahap promosi, dimana terdapat dosen yang memiliki masa kerja lama masih cenderung berada pada zona nyaman dan tidak tertantang untuk melakukan perubahan bagi organisasi. Permasalahan dari implementasi manajemen keragaman terutama disebabkan oleh sikap resistensi terhadap perubahan dan kebijakan organisasi (Vashanti, 2012).

Permasalahan yang terjadi diluar praktik MSDM seperti masalah komunikasi adalah muncul karena harus melibatkan interaksi dengan berbagai ras dan etnis yang berbedabeda, sehingga terjadinya kesulitan dalam memahami masing-masing karakter dengan cepat. Selain itu, masih adanya cara pandang yang berbeda-beda dari setiap individu sehingga dapat timbul stereotype tertentu. Temuan tersebut diperkuat dengan penelitian Abugu \& Jerry (2018) yang menemukan bahwa permasalahan implementasi manajemen keragaman disebabkan oleh akibaat kesulitan dalam komunikasi. Permasalahan implementasi manajemen keragaman terjadi ketika munculnya stereotype dan karakteristik yang berbeda-beda sehingga sulit untuk memahaminya (Wambui, et al., 2013).

\section{Pembahasan}

Berdasarkan hasil-hasil penelitian yang diperoleh maka dapat dikemukakan sejumlah implikasi bersifat teoritis maupun praktis.

Peran dari pihak universitas dalam penerapan manajemen keragaman sangatlah penting. Secara teoritis, penelitian ini berkontribusi dalam memperluas penelitian kebijakan universitas berkaitan dengan upaya implementasi manajemen keragaman dalam hubungannya dengan praktik MSDM. Dalam penelitian ini, kebijakan diidentifikasi dilakukan dari tahapan rekrutmen, seleksi, promosi, pelatihan kompensasi dan pemberian jaminan kesehatan. Tahap-tahapan ini sejalan dengan beberapa penelitian terdahulu, seperti Femi \& Prasetya (2017) serta Meena \& Vanka (2017).

Dalam penelitian ini juga ditemukan bahwa tahapan rekrutmen, seleksi, promosi, pelatihan dan kompensasi didasarkan pada prinsip "the right man in the right place", sesuai dengan kapabilitas yang dimiliki yang selanjutnya akan berbasis pada kinerja. Hasil 
penelitian ini mendukung temuan riset yang diperoleh Horwitz \& Horwitz (2007) serta Bleijenbergh et al. (2010) yang menyebutkan bahwa manajemen keragaman merupakan sebuah 'pendekatan inklusif' dengan proses merekrut, memilih, mengangkat dan menempatkan karyawan sesuai dengan kemampuan, sikap, nilai-nilai yang tidak terlihat serta pengalaman yang dimiliki.

Berikutnya, berdasarkan hasil penelitian ini dapat dinyatakan sejumlah implikasi praktis pada pihak universitas. Pertama, implementasi manajemen keragaman dalam kaitannya dengan praktik MSDM telah dilakukan dengan baik yang berbasis pada kinerja, adil dan tidak terjadi perlakuan diskriminasi. Untuk mempertahankan kondisi ini maka disarankan agar pihak universitas tetap konsisten dalam mengelola keragaman yang ada. Kedua, untuk masa yang akan datang diharapkan universitas dapat membuat dan menggabungkan program-program pelatihan keragaman dengan pelatihan yang merujuk kepada kapabilitas sehingga dosen lebih aware lagi terhadap perbedaan yang ada dan menghargai kemampuan yang dimiliki. Ketiga, pihak universitas juga dapat memberikan langkah pemecahan atas permasalahan yang ditemui, misalnya selalu melakukan komunikasi dengan cara musyawarah dan bersikap netral, memastikan komitmen studi lanjut di awal perekrutan bagi dosen wanita, ketegasan pemberian target pekerjaan, serta mempelajari karakteristik dan cara penyelesaian kasus yang terjadi.

\section{SIMPULAN}

Berdasarkan dari permasalahan, tujuan, hasil penelitian dan pembahasan, maka dapat ditarik beberapa kesimpulan berikut.

Kesimpulan pertama adalah bahwa praktik implementasi manajemen keragaman MSDM telah dilakukan dengan baik yang berbasis pada kinerja, adil dan tidak terdapat perlakuan diskriminasi. Praktik itu dilakukan dari tahapan rekrutmen, seleksi, promosi, pelatihan, sampai kompensasi dan pemberian jaminan kesehatan. Pada tahap rekrutmen, seleksi, promosi, pelatihan dan kompensasi didasarkan pada prinsip "the right man in the right place" sesuai dengan kapabilitas yang dimiliki yang kemudian akan berbasis pada kinerja. Namun berbeda dengan tahap pemberian jaminan kesehatan yang didasarkan pada lama masa kerja sehingga menentukan besar kecilnya iuran yang dibayarkan. Selain itu, pada tahap rekrutmen dan seleksi aspek agama, umur dan masa kerja yang sesuai kriteria lebih diprioritaskan karena telah diatur dalam SOP yayasan dan universitas. Perlakuan tersebut tidak dapat dikatakan sebagai diskriminasi karena merupakan kebijakan dari organisasi.

Kedua disimpulkan bentuk pelaksanaan manajemen keragaman ditunjukkan dengan mengadakan kegiatan ibadah rutin dan kegiaan-kegiatan lain yang bersifat mempersatukan seperti expo budaya dan senam nusantara, pemberian kesempatan kerja yang sama, pengembangan diri, penyediaan fasilitas ruangan bagi pimpinan dan wanita yang telah melahirkan pemberian cuti, pengalihan pekerjaan yang melibatkan fisik, perpanjangan masa pensiun serta pemberian penghargaan bagi dosen berprestasi. Selain itu, ditunjukkan dengan pemberian kebebasan perekrutan, pengembangan budaya organisasi melalui sikap dan penyediaan pelatihan bagi dosen yang mengalami kesulitan dalam penulisan riset.

Kesimpulan katiga bahwa permasalahan implementasi yang ditemui pada UKSW terbagi menjadi dua bagian, yaitu praktik di dalam serta diluar MSDM. Permasalahan praktik di dalam MSDM terjadi pada tahapan pelatihan dan tahap promosi. Permasalahan yang terjadi diluar praktik MSDM seperti masalah komunikasi dan masih cara pandang 
yang berbeda-beda. Langkah pemecahan yang diberikan untuk mengatasi masalah ini adalah dengan memastikan komitmen studi lanjut di awal perekrutan bagi dosen wanita, ketegasan pemberian target pekerjan, mempelajari karakteritik dan cara penyelesaian kasus, serta selalu melakukan komunikasi dengan cara musyawarah dan bersikap netral.

Pada bagian akhir tulisan ini, penulis menyadari bahwa meskipun penelitian ini telah diusahakan dan dilaksanakan sesuai dengan prosedur ilmiah, namun demikian masih memiliki beberapa keterbatasan. Keterbatasan pertama adalah keterbatasan dalam menggali informasi mendalam dari para informan dimana karena kesibukan mendadak yang mereka hadapi menyebabkan waktu wawancara yang diberikan terlalu singkat dan menimbulkan potensi jawaban yang diberikan tidak akurat. Akibatnya juga proses triangulasi tidak dapat dilaksanakan dengan baik dan tidak lengkap.

Keterbatasan kedua bahwa penelitian ini hanya meneliti pada satu organisasi yang memiliki keragaman sumber daya manusia di dalamnya, sehingga hasil yang diperoleh belum dapat mewakili dan menggambarkan situasi sebenarnya terkait dengan proses implementasi manajemen keragaman dalam kaitannya dengan MSDM yang ada di seluruh organisasi. Keterbatasan ketiga adalah bahwa penelitian ini hanya berpatokan pada derajat keragaman karakteristik pribadi seperti agama, gender, umur, masa kerja, ras dan etnis; sehingga hasil yang diperoleh belum dapat mewakili dan memberikan gambaran seluruh karakteristik yang ada.

Agar sejumlah keterbatasan itu bisa ditindaklanjuti oleh para peneliti berikutnya, maka disarankan beberapa hal. Pertama, penelitian selanjutnya dapat menjadwalkan waktu wawancara dengan menyesuaikan kesibukan dari para narasumber, sehingga data yang diperoleh bersifat akurat dan proses triangulasi dapat dilaksanakan dengan baik. Kedua, penelitian selanjutnya bisa menambah beberapa organisasi yang dipandang juga memiliki keragaman, sehingga hasil yang diperoleh dapat lebih lengkap dan menggambarkan situasi sebenarnya yang terjadi di seluruh organisasi. Terakhir, disarankan agar penelitian berikutnya bisa mengatasi keterbatasan penelitian ini dengan menambahkan karakteristik kapabilitas yang merupakan temuan di dalam penelitian ini dengan karakteristik lainnya yang diperlukan untuk mendukung penelitian.

\section{REFERENSI}

Abugu, S. O., \& Jerry, E. E., (2018). Workforce diversity management in Nigeria public service: Problems and prospects. Global Journal of Human Resource Management, 6(1), 35-50. Retrieved from https://www.eajournals. org/journals/global-journal-of-humanresource-management-gjhrm/vol-6issue-1-march-2018/workforcediversity-management-in-nigeriapublic-service-problems-and-prospects/

Ahonen, P., \& Tienari, J. (2009). United in diversity? Disciplinary normalization in an EU Project. Organization, 16(5), 655-679. doi: 10.1177/1350508409338 434.

Ali, S., Burns, C., \& Grant, L. (2013). Equality and diversity in the health service: An evidence-led culture change. Journal of Psychological Issues in Organizational Culture, 3(S1), 190209. doi: 10.1002/jpoc.v3.1s.

Ardakani, M. S., Abzari, M., Shaemi, A., \& Fathi, S. (2016). Diversity management and human resources productivity: Mediating effects of perceived organizational attractiveness, organizational justice and social identity in Isfahan's steel industry. Iranian Journal of Management Studies (IJMS), 9(2), 407432. doi: 10.22059/ijms.2016.56412. 
Ayega, E. N., \& Muathe, S. (2018). Critical review of literature on cultural diversity in the work place and organizational performance: A research agenda. Journal of Human Resource Management, 6(1), 9-17. doi: 10.11648/j.jhrm. 20180601.12 .

Bangun, W. (2012). Manajemen sumber daya manusia. Erlangga.

Bedi, P., Lakra, P., \& Gupta, E. (2014). Workforce diversity management: biggest challenge or opportunity for $21 \mathrm{st}$ century organizations. IOSR Journal of Business and Management, 16(4), 102-107. doi: 10.9790/487X1643102107.

Bleijenbergh, I., Peters, P., \& Poutsma, E. (2010). Diversity management beyond the business case. Equality, Diversity and Inclusion: An International Journal, 29(5), 413-421. doi: 10.1108/ 02610151011052744.

Chi, N. W., Huang, Y. M., \& Lin, S. C. (2009). A double-edged sword? Exploring the curvilinear role, relationship between organizational tenure diversity and team innovation: the moderating of team-oriented HR practices. Group and Organization Management, 34(6), 698-726. doi: 10. 1177/1059601109350985.

Choi, S., \& Rainey, H. G. (2010). Managing diversity in U.S. federal agencies: Effects of diversity and diversity management on employee perceptions of organizational performance. Public Administration Review, 70(1), 109-121. doi: 10.1111/j.1540-6210.2009.02115.x

Cooke, F. L. \& Saini, D. S. (2012). Managing diversity in Chinese and Indian organizations: A qualitative study. Journal of Chinese Human Resources Management, 3(1), 16-32. doi: 10. 1108/20408001211220548.

Femi, B., \& Prasetya, A. (2017). Penerapan diversity management dalam rangka meraih competitive advantage (Studi pada PT. Petrokimia Gresik). Jurnal Administrasi Bisnis, 50(5), 37-47.
Retrieved from http://administrasi bisnis.studentjournal.ub.ac.id/index.php /jab/article/view/2053.

Foley, S., Ngo, H-Y., Loi, R., \& Zheng, X. (2015). Gender, gender identification and perceived gender discrimination: An examination of mediating processes in China. Equality, Diversity and Inclusion: An International Journal, 34(8), 650-665. doi: 10.1108/EDI-052015-0038.

Garg, P., \& Panchal, M. (2016). Managing workforce diversity to improve business performance - A study on MNCs in Delhi Region. BEST: International Journal of Management, Information, Technology and Engineering (BEST: IJMITE), 4(10), 29-34. Retrieved from https://www. researchgate.net/publication/326607242 _MANAGING_WORKFORCE_DIVE RSITY_TO_IMPROVE_BUSINESS_P ERFORMANCE_-_A_STUDY_ON_ MNCS_IN_DELHI_REGION.

Gómez-Mejia, L. R., Balkin, D. B., \& Cardy, R. L. (2012). Managing human resources $\left(7^{\text {th }}\right.$ ed.). Pearson Prentice Hall.

Greenberg, E. S., Sikora, P. B., Grunberg, L., \& Moore, S. (2009). Work teams and organizational commitment: Exploring the influence of the team experience on employee attitudes. Working Paper, Workplace Change Project WP-012, 147. Retrieved from https://ibs.colorado. edu/workplacechange/papers/WP_012. pdf.

Harrisr, L., \& Foster, C. 2010. Aligning talent management with approaches to equality and diversity: Challenges for UK public sector managers. Equality, Diversity and Inclusion: An International Journal, 29(5), 422-435. doi: 10.1108/02610151011052753.

Hayes, D. K., \& Niemeier, J. D. (2009). Human resources management in the hospitality industry. John Wiley \& Sons. 
Horwitz, S. K., \& Horwitz, I. B. (2007). The effects of team diversity on team outcomes: A meta-analytic review of team demography. Journal of Management, 33(6), 987-1015. doi: 10.1177/ 0149206307308587.

Hudson, Jr., S. W. (2014). Diversity in the workforce. Journal of Education and Human Development, 3(4), 73-82. doi: 10.15640/jehd.v3n4a7.

Hunt, B. (2007). Managing equality and cultural diversity in the health workforce. Journal of Clinical Nursing, 16(12), 2252-2259. doi: 10.1111/jen. 2007.16.issue-12.

Jayne, M. E. A., \& Dipboye, R. L. (2004). Leveraging diversity to improve business performance: Research findings and recommendations for organizations. Human Resource Management. 43(4): 409-424. doi: 10. 1002/hrm.20033.

Kundu, S. C., \& Mor, A. (2017). Workforce diversity and organizational performance: a study of IT industry in India. Employee Relations, 39(2), 160183. doi: 10.1108/ER-06-2015-0114.

Meena, K., \& Vanka, S. (2017). Developing an empirical typology of diversityoriented human resource management practices. Journal of Management Development, 36(7), 915-929. doi: 10. 1108/JMD-02-2016-0031.

Page, M. (2018). Salary benchmark 2018. Retrieved from https://www.michael page.co.id/sites/michaelpage.co.id/files/ Indonesia-MP-Salary-Benchmark2018.pdf.

Patrick, H. A., \& Kumar, V. R. (2012). Managing workplace diversity: issues and challenges. SAGE Open, 2(2), 115. doi: $10.1177 / 2158244012444615$.

Robbins, S. P., \& Judge Timothy A. (2015). Organizational behavior $\left(16^{\text {th }}\right.$ ed., P. P. Lestari, Trans.). Salemba Empat.

Roberge, M.-E., Lewicki, R. J., Hietapelto, A., \& Abdyldaeva, A. (2011). From theory to practice: Recommending supportive diversity practices. Journal of Diversity Management (JDM), 6(2), 1-20. doi: 10.19030/jdm.v6i2.5481.

Roh, H., \& Kim, E. (2016). The business case for gender diversity: Examining the role of human resource management investments. Human Resource Management, 55(3), 519-534. doi: 10.1002/ hrm. 21736.

Saxena, A. (2014). Workforce diversity: A key to improve productivity. Procedia Economics and Finance, 11(14), 76-85. doi: 10.1016/S2212-5671(14)00178-6.

Sharma, A. (2016). Managing diversity and equality in the workplace. Cogent Business \& Management, 3(1), 1-14. doi: 10.1080/23311975.2016.1212682.

Stainback, K., Jason, K., \& Walter, C. (2018). Organizational context and the wellbeing of black workers: Does racial composition affect. Race, Identity and Work (Research in the Sociology of Work, Vol. 32), Emerald Publishing Limited, 137-164. doi: 10.1108/S0277283320180000032010.

Thomas, R. R., Jr. (2012). Organizational diversity: A missed opportunity. Employment Relations, 38(4), 1-8. doi: 10.1002/ert.20359.

Vashanti, P. S. (2012). Diversity management time for a new approach in an organization. IOSR Journal of Business and Management (IOSRJBM), 3(3), 44-50. doi: 10.1177/009102600002900 106.

Wambui, T. W., Wangombe, J. G., Muthura, M. W., Kamau, A. W., \& Jackson, S. M. (2013). Managing workplace diversity: A Kenyan perspective. International Journal of Business and Social Science, 4(16), 199-218. Retrieved from https://www.research gate.net/publication/303893112_Manag ing_Workplace_DiversityA_Kenyan_P erspective. 